\title{
PENGEMBANGAN MODUL IPA TERPADU BERBASIS LITERASI SAINS PADA MATERI TEKANAN ZAT
}

\author{
Maya Pujowati ${ }^{1)}$; Yusuf Bungkang ${ }^{2)}$; Albert Lumbu ${ }^{3)}$ \\ ${ }^{1)}$ Madrasah Tsanawiyah Darul Dakwah Wa'Irsyad (DDI) Jayapura; pujowati_maya@yaho.com \\ ${ }^{2)}$ Program Studi Magister Pendidikan IPA UNCEN; bungkangyusuf@gmail.com \\ ${ }^{3)}$ Program Studi Magister Pendidikan IPA UNCEN; albertlumbu@gmail.com
}

\begin{abstract}
This research is research and development with the aim to find out how to develop integrated science learning modules based on scientific literacy in the material pressure of eighth grade Madrasah Tsanawiyah Darul Dakwah Wa'Irsyad (DDI) students in Jayapura. The number of samples in this study 25 with descriptive descriptive data analysis techniques to determine the feasibility of the module. The results showed that: (1) Module development with the stages of information gathering, planning, development, validation and testing; (2) The feasibility of the prepared learning module, based on the validator of the material obtained an average of $90 \%$ with a feasible category, the validator of the media obtained an average of $91 \%$ with a feasible category, while the results of the responses of students with an average of $77.76 \%$ with quite interesting categories, (3) There is an increase in the learning outcomes of students in class VIII by learning to use an integrated science module material pressure based on scientific literacy with $n$-Gain RPP-1 values of $0.61, R P P-2$ of 0.71, RPP-3 of 0.91, RPP-4 of 0.71, RPP-5 is 0.80, and n-gain is on average 0.80 with high category.
\end{abstract}

Keywords: Development of learning modules; based on scientific literacy; substance pressure

\begin{abstract}
ABSTRAK
Penelitian ini merupakan penelitian dan pengembangan dengan tujuan untuk mengetahui cara pengembangan modul pembelajaran IPA terpadu berbasis literasi sains pada materi tekanan zat peserta didik kelas VIII Madrasah Tsanawiyah Darul Dakwah Wa'Irsyad (DDI) Jayapura. Jumlah sampel pada penelitian ini 25 dengan teknik analisa data deskriptif presentatif untuk mengetahui kelayakan modul. Hasil penelitian menunjukkan bahwa: (1) Pengembangan modul dengan tahapan pengumpulan informasi, perencanaan, pengembangan, validasi dan uji coba; (2) Kelayakan modul pembelajaran yang disusun, berdasarkan validasi validator materi diperoleh rerata sebesar $90 \%$ dengan kategori layak, validasi validator media diperoleh rerata sebesar $91 \%$ dengan kategori layak, sedangkan hasil respon peserta didik dengan rerata 77,76 \% dengn kategori cukup menarik, (3) Terdapat peningkatan hasil belajar peserta didik kelas VIII dengan pembelajaran menggunakan modul IPA terpadu materi tekanan zat berbasis literasi sains dengan nilai n-Gain RPP-1 sebesar 0,61, RPP-2 sebesar 0,71, RPP-3 sebesar 0,91, RPP-4 sebesar 0,71, RPP-5 sebesar 0,80, dan n-Gain rata-rata sebesar 0,80 dengan kategori tinggi.
\end{abstract}

Kata Kunci : "Pengembangan modul pembelajaran; berbasis literasi sains; tekanan zat

PENDAHULUAN

Tujuan Pembelajaran IPA terpadu akan tercapai jika terdapat penunjang dalam pelaksanaannya. Beberapa penunjang terlaksananya tujuan pembelajaran IPA terpadu adalah guru dan bahan ajar yang digunakan. Salah satu komponen penting dalam proses 
pembelajaran adalah model yang digunakan oleh guru. Model pembelajaran yang dapat diterapkan untuk mencapai tujuan pembelajaran IPA terpadu adalah dengan menggunakan model pembelajaran terpadu.

Keterpaduan bidang kajian dapat mendorong guru untuk mengembangkan kreativitas tinggi karena adanya tuntutan untuk memahami keterkaitan antara satu materi dengan materi lainnya. Peserta didik akan lebih mudah memahami konsep pembelajaran IPA terpadu ketika model pembelajaran benar-benar diterapkan oleh guru sesuai dengan tujuan pembelajaran IPA terpadu itu sendiri. Menurut Trianto (2011), pembelajaran terpadu menuntut kemampuan belajar peserta didik yang relatif baik, baik dalam kemampuan akademik maupun kreativitasnya.

Penunjang pembelajaran selain guru adalah bahan ajar yang digunakan saat proses pembelajaran berlangsung. Bahan ajar yang dikembangkan dapat berupa bahan cetak, film, audio tape, videotape, peta, globe, carta atau kombinasi keduanya. Menurut (Firman 2007:23), diharapkan bahwa bahan ajar yang dikembangkan dapat menjadi sarana belajar untuk mempermudah peserta didik dalam menangkap materi pembelajaran yag diajarkan. Bahan ajar yang dimaksud adalah modul. Modul memiliki peranan penting dalam implementasi kurikulum 2013 dan salah satu bentuk bahan ajar yang dikemas secara utuh dan sistematis, didalamnya memuat seperangkat pengalaman belajar yang terencana dan didesain untuk membantu peserta didik menguasai tujuan belajar yang spesifik. Sehingga modul tersebut dapat dijadikan sebagai pendukung dalam proses pembelajaran menggunakan kurikulum 2013 yang mengacu pada pendekatan saintifik

Dalam bidang sains, literasi berarti kemampuan memahami, berpikir dan mengaplikasikan konsep dan perspektif sains dalam berbagai kejadian (Abidin,2014:182). Literasi sains adalah kemampuan untuk terlibat dengan isu-isu yang berkaitan dengan sains, dan dengan ide-ide sains sebagai warga negara yang reflektif (OECD, 2013).

Dewasa ini, kemampuan literasi sains peserta didik Indonesia masih rendah. Hal ini sejalan dengan pendapat Rusilowati (2013) bahwa kemampuan peserta didik Indonesia dalam bidang sains khususnya literasi sains semakin lemah. Menurunnya hasil kemampuan literasi sains peserta didik Indonesia disebabkan oleh beberapa faktor. Salah satu faktor rendahnya literasi sains karena buku ajar yang digunakan belum menunjukkan keseimbangan kategori literasi sains (Firman: 2007).

Berdasarkan hasil observasi peneliti yang dilakukan di Madrasah Tsanawiyah Darul Dakwah Wa' Irsyad (DDI) Jayapura pada bulan Agustus 2018 ditemukan 
bahwa, buku ajar IPA Kelas VIII yang digunakan sebagai buku pegangan peserta didik dan guru adalah buku Lembar Kerja Peserta Didik IPA untuk kelas VIII. Di dalam buku ajar tersebut memiliki proporsi atau presentase muatan literasi sains yang kurang seimbang dikarenakan belum terkandung aspek interaksi antara sains, teknologi dan masyarakat.

Hasil dari pemikiran tersebut, dapat dikatakan bahwa kesiapan dan penggunaan acuan dalam pembelajaran modul secara baik, menarik dan tepat, pada akhirnya secara akumulatif dapat meningkatkan motivasi dan hasil belajar peserta didik. Hal ini sesuai dengan Abulia Realita (2016) yang menyatakan bahwa terjadi peningkatan motivasi dan hasil belajar pada peserta didik yang mengikuti pembelajaran menggunakan model integrasi literasi sains.

\section{METODE PENELITIAN}

Adapun yang menjadi jenis penelitian ini adalah penelitian pengembangan (Research \& Development/ $R \& D$ ) yang mengikuti tahap-tahap pengembangan model 4-D yaitu 4 tahap pengembangan, yaitu Define (pendefinisian), Design (Perencanaan), Develop (Pengembangan), dan Disseminate (Penyebaran). Penelitian ini dilaksanakan di MTs DDI Jayapura yang terletak di jalan raya Abepura Entrop pada peserta didik kelas VIII.

Uji coba terbatas dilaksanakan di Madrasah Tsanawiyah Darul Dakwah
Wa'Irsyad Jayapura. Subjek uji coba adalah peserta didik kelas dan uji coba luas dilakukan untuk pengujian bahan ajar modul yang dikembangkan dengan rancangan eksperimen "One Group Pretest-Posttest Design".

$$
\mathrm{O}_{1} \times \mathrm{O}_{2}
$$

Keterangan:

$\mathrm{O}_{1}$ menyatakan Pretest $\mathrm{O}_{2}$ menyatakan Post test dan $\mathrm{X}$ menyatakan Pembelajaran dengan menggunakan modul.

\section{HASIL DAN PEMBAHASAN}

1. Cara Pengembangan Isi Modul Pembelajaran IPA Terpadu pada Materi Tekanan Zat berbasis Literasi Sains Peserta Didik Kelas VIII MTs Darul Dakwah Wa'Irsyad (DDI) Jayapura

Modul pembelajaran IPA Terpadu pada materi tekanan zat berbasis literasi sains kelas VIII terdiri 3 (tiga) komponen yaitu:

a. Bagian pendahuluan yang terdiri dari halaman judul, latar belakang, tujuan, peta kompetensi, ruang lingkup, dan cara penggunaan modul.

b. Bagian isi yang terdiri dari tujuan pembelajaran, indikator pencapaian kompetensi, uraian materi, aktivitas pembelajaran (dalam bentuk kegiatan pembelajaran di kelas), rangkuman, umpan balik dan latihan soal.

c. Bagian penutup yang terdiri dari glosarium dan daftra pustaka. 
Tahapan dalam pengembangan modul pembelajaran IPA terpadu pada materi tekanan zat berbasis literasi sains adalah sebagai berikut: a) pengumpulan informasi; b) perencanaan; c) pengembangan produk; d) validasi; e) uji coba.
2. Kelayakan Modul Pembelajaran IPA Terpadu pada Materi Tekanan Zat berbasis Literasi Sains

Kelayakan modul pembelajaran tekanan zat berbasis literasi sains ini dapat dilihat dari validasi validator materi dan validator media, ditunjukan pada Tabel 1 dan 2 sebagai berikut:

Validasi Materi (Tabel 1. Validasi Aspek Isi (materi dari Ahli Isi Materi Pembelajaran)

\begin{tabular}{|c|l|c|}
\hline No & \multicolumn{1}{|c|}{ Indikator pencapaian } & Skor \\
\hline 1 & Cakupan materi & $80 \%$ \\
\hline 2 & Akurasi materi & $95 \%$ \\
\hline 3 & Kemutakhiran & $90 \%$ \\
\hline 4 & Merangsang keingintahuan & $90 \%$ \\
\hline 5 & Merangsang wawasan literasi & $90 \%$ \\
\hline 6 & Teknik penyajian & $95 \%$ \\
\hline 7 & Pendukung penyajian materi & $90 \%$ \\
\hline 8 & Penyajian pembelajaran & $88 \%$ \\
\hline 9 & Literasi sains & $90 \%$ \\
\hline 10 & Penanaman nilai-nilai literasi sains & $95 \%$ \\
\hline 11 & Manfaat literasi sains & $85 \%$ \\
\hline 12 & Kesesuaian dengan perkembangan dengan peserta didik & $93 \%$ \\
\hline 13 & Komuniktif & $87 \%$ \\
\hline 14 & Dialogis dan interaktif & $90 \%$ \\
\hline 15 & Lugas & $90 \%$ \\
\hline 16 & Kesesuaian dengan kaidah bahasa Indonesia & $93 \%$ \\
\hline \multicolumn{2}{l}{ Rata-rata Presentase } & $90 \%$ \\
\hline
\end{tabular}

Validasi Media ( Tabel 2. Aspek Penilaian Produk (Ahli Media Pembelajaran)

\begin{tabular}{|c|l|c|}
\hline No & \multicolumn{1}{|c|}{ Indikator pencapaian } & Skor \\
\hline 1 & Konsistensi & $89 \%$ \\
\hline 2 & Penampilan fisik & $93 \%$ \\
\hline 3 & Bentuk dan ukuran huruf & $90 \%$ \\
\hline 4 & Komunikatif & $83 \%$ \\
\hline 5 & Dialogi dan interaktif & $97 \%$ \\
\hline 6 & Lugas & $87 \%$ \\
\hline 7 & Kesesuaian dengan kaidah bahasa Indonesia & $93 \%$ \\
\hline 8 & Teknik Penyajian & $90 \%$ \\
\hline 9 & Pendukung Penyajian & $91 \%$ \\
\hline 10 & Penyajian Materi Pembelajaran & $90 \%$ \\
\hline \multicolumn{2}{|l|}{ Rata-rata Presentase } & $90 \%$ \\
\hline
\end{tabular}




\section{Peningkatan Hasil Belajar IPA}

Menggunakan Modul Pembelajaran

IPA Terpadu pada Materi Tekanan

\section{Zat berbasis Literasi Sains}

Hasil uji n-Gain menunjukkan bahwa pada RPP-1 diperoleh n-Gain sebesar 0,61 dengan kategori sedang, hal ini menunjukkan bahwa pembelajaran dengan modul cukup efektif dalam meningkatkan prestasi belajar peserta didik. Pada RPP-2 diperoleh n-Gain sebesar 0,71 dengan kategori tinggi, hal ini menunjukkan bahwa secara umum penggunaan modul pembelajaran IPA berbasis literasi sains efektif meningkatkan belajar peserta didik, walaupun secara individu pada RPP-1 terdapat peserta didik yang mempunyai nGain 0 atau prestasinya rendah, hal ini disebabkan oleh kurangnya pengawasan pada saat pre test sehingga peserta didik tersebut melihat jawaban teman sebangkunya. Pada RPP-3 diperoleh nGain 0,91 dengan kategori tinggi, hal ini menunjukkan peningkatan belajar yang efektif dan peserta didik sangat tertarik untuk mempelajari modul IPA terpadu berbasis literasi sains. Pada RPP-4 diperoleh n-Gain 0,71 dengan kategori sedang, hal ini menunjukkan penurunan belajar dibandingkan pada RPP-3, hal ini disebabkan karena kondisi kelas yang terbatas, sehingga pembelajaran tidak efisien dan peserta didik tidak konsentrasi dalam pembelajaran. Pada RPP-5 diperoleh n-Gain 0,80 dengan kategori tinggi, hal ini menunjukkan peningkatan belajar yang efektif dan peserta didik kembali memiliki konsentrasi karena kondisi kelas sudah kembali baik sehingga peserta didik sangat tertarik untuk mempelajari modul pembelajaran IPA terpadu berbasis literasi sains.

Berdasarkan hasil uji n-Gain rata-rata sebesar 0,75 dalam kategori tinggi, maka pembelajaran dengan menggunakan modul IPA terpadu berbasis literasi sains materi tekanan zat efektif untuk meningkatkan hasil belajar. Hal ini sesuai dengan penelitian yang dilakukan oleh Ita Risahondua (2018) yang menyatakan bahwa modul IPA mampu meningkatkan minat belajar IPA sebesar 0,40 dengan kategori sedang, yang artinya bahwa modul IPA memberikan dampak positif bagi peserta didik dalam belajar, sehingga proses sains efektif digunakan dalam pembelajaran. Hal ini juga sesuai dengan penelitian yang dilakukan oleh Desvita Astari, Simon dkk (2018) yang menyatakan bahwa modul IPA dapat digunakan sebagai penunjang kelengkapan dalam pembelajaran IPA serta dapat membuat peserta didik kreatif, dan dapat membantu peserta didik dalam memahami materi yang diajarkan.

\section{SIMPULAN DAN SARAN}

SIMPULAN

Modul IPA terpadu berbasis literasi sains pada materi tekanan zat cukup layak dengan presentase sebesar $84 \%$ dan 
peningkatan hasil belajar IPA sebesar 0,75 dengan kategori tinggi.

\section{SARAN}

Pengembangan modul ini diharapkan menjadi cikal bakal untuk para guru mata pelajaran lain untuk menyusun modul berdasarkan literasi sains. Selain itu dapat dilakukan penelitian-penelitian lainnya yang berbasis literasi sains pada pelajaran selain IPA.

\section{UCAPAN TERIMA KASIH}

Kepala Sekolah Madrasah

Tsanawiyah Darul Dakwah Wa'Irsyad (DDI) Jayapura yang telah bekerjasama dengan Ketua Program Studi Magister Pendidikan IPA dalam penelitian ini.

\section{DAFTAR PUSTAKA}

Abidin, Y, 2014, Desain Sistem Pembelajaran Dalam Konteks Kurikulum 2013, Bandung, Refika Aditama;

Abulia Realita, Sukarmin, dan Sarwanto, 2016, Pengembangan Modul Fisika Berbasis Sains Teknologi Masyarakat (STM) pada Materi Fluida Statis Untuk Meningkatkan Motivasi dan Hasil Belajar Siswa SMA Kelas X, Jurnal Inkuiri Magister Pendidikan Sains, Fakultas Keguruan dan Ilmu Pendidikan, Universitas Sebelas Maret Surakarta;

Desvita Astari Djamion, 2018, Pengembangan Modul IPA Berbasis Inkuiri Terbimbing Pada Materi Kalor Dan Perpindahannya Peserta Didik Kelas VII MTs Muhammadiyah Jayapura, Papua,
Jurnal Ilmu Pendidikan Indonesia, Vol 6 (2) 14 - 23;

Firman, H. 2007, Analisis Literasi Sains Berdasarkan Hasil PISA Nasional Tahun 2006, Jakarta, Pusat Penilaian Pendidikan Balitbang Depdiknas;

Ita Risahondua, 2018, Pengembangan Modul IPA Terpadu Materi Gerak Melalui Pendekatan Keterampilan Proses Sains Pada Peserta Didik Kelas VIII SMP Hikmah Yapis Jayapura, Jurnal Ilmu Pendidikan Indonesia Vol 6 (2) 47 - 53;

OECD, 2013, PISA 2015 Draft Science Framework. OECD, Paris, OECD; , 2014, PISA 2012 Result in Focus, What 15 - Year - Olds Know and WhatThey can Do with What They Know (Student Performance in Mathematics, Reading and Sciences), Paris, OECD;

Rusilowati, 2013, Peningkatan Literasi Sains Peserta didik melalui Pengembangan Instrumen Penilaian, Pidato Pengukuhan Profesor Unnes Semarang;

Simon Kalemben, Basa T. Rumahorbo dan Johnson Siallagan, 2018, Pengembangan Modul IPA Terpadu Berbasis Inkuiri Terbimbing Untuk Meningkatkan Keterampilan Proses Sains, Minat, Dan Hasil Belajar Siswa Pada Materi Fotosintesis Di Kelas VIII SMP Negeri 9 Jayapura, Jurnal Ilmu Pendidikan Indonesia, Vol 6 (3) 62 - 70;

Trianto, 2011, Model Pembelajaran Terpadu, Jakarta, Bumi Aksara. 